\title{
Apakah Tanggung Jawab Sosial Perusahaan Memediasi Pengaruh Karakteristik CEO terhadap Tingkat Penghindaran Pajak?
}

\author{
Sulaksono Suryo Pranoto ${ }^{1}$ \\ Fakultas Ekonomi dan Bisnis \\ Universitas Airlangga, Indonesia
}

\author{
I Made Narsa ${ }^{2}$ \\ Fakultas Ekonomi dan Bisnis \\ Universitas Airlangga, Indonesia
}

Surel : sulaksono.suryo.pranoto-2017@feb.unair.ac.id

\section{ABSTRAK}

Tujuan penelitian ini adalah untuk menguji secara empiris Apakah CSR dapat memediasi pengaruh karakteristik CEO terhadap tingkat penghindaran pajak. Variabel yang diteliti adalah pengalaman politik; afiliasi akademi; latar belakang pendidikan di luar negeri; jenis kelamin. Sampel dalam penelitian ini adalah perusahaan manufaktur yang terdaftar di IDX pada tahun 2017-2018, 632 Perusahaan yang listing Perusahaan Manufaktur terdapat sejumlah 179 Perusahaan. Penelitian ini menggunakann purposive sampling pada perusahaan manufaktur yang memenuhi kriteria - kriteria tertentu. Teknik analisis yang digunakan adalah analisis jalur. Penelitian ini menghasilkan temuan Analisis CSR dapat memediasi pengaruh pengalaman politik terhadap tingkat penghindaran pajak; CSR dapat memediasi pengaruh afiliasi akademi terhadap tingkat penghindaran pajak; CSR dapat memediasi pengaruh latar belakang pendidikan diluar negeri terhadap tingkat penghindaran pajak; CSR dapat memediasi pengaruh jenis kelamin terhadap tingkat penghindaran pajak.

Kata Kunci: Tanggung Jawab Sosial Perusahaan; Pengalaman Politik; Afiliasi Akademi; Latar Belakang Pendidikan Diluar Negeri; Jenis Kelamin; Tingkat Penghindaran Pajak.

\section{Does Corporate Social Responsibility Mediate the Effect of CEO Characteristics on Tax Avoidance Rates?}

\section{ABSTRACT}

The purpose of this study is to test empirically whether CSR can mediate the effect of CEO characteristics on the level of tax avoidance. The variables studied were political experience; academy affiliation; educational background abroad; gender. The sample in this study were manufacturing companies listed on IDX in 2017-2018, there are 179 companies listed in manufacturing companies. This study uses purposive sampling on manufacturing companies that meet certain criteria. The analysis technique used is path analysis. This study produces findings that CSR analysis can mediate the effect of political experience on the level of tax avoidance; CSR can mediate the effect of academic affiliation on the level of tax avoidance; CSR can mediate the influence of educational backgrounds abroad on the level of tax avoidance; CSR can mediate the effect of gender on the level of tax avoidance.

Keywords: $\quad$ Corporate Social Responsibility; Political Experience; Academy Affiliates; Overseas Educational background; Gender; Tax Avoidance Rates.

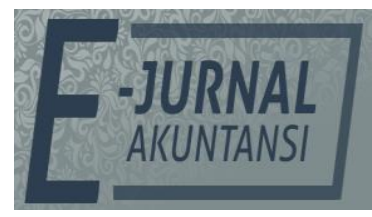

e-ISSN 2302-8556

Vol. 31 No. 1

Denpasar, Januari 2021

Hal. 15-31

DOI:

10.24843/EJA.2021.v31.i01.p02

PENGUTIPAN:

Pranoto, S.S., \& Narsa, I M. (2021). Apakah Tanggung Jawab Sosial Perusahaan

Memediasi Pengaruh Karakteristik CEO terhadap

Tingkat Penghindaran

Pajak? E-Jurnal Akuntansi, 31(1), 15-31

RIWAYAT ARTIKEL: Artikel Masuk: 10 September 2020 Artikel Diterima: 11 Januari 2021

Artikel dapat diakses : https://ojs.unud.ac.id/index.php/Akuntansi/index 


\section{PENDAHULUAN}

Sejak Februari tahun 2020 Indeks harga saham gabungan Bursa Efek Indonesia berwajah suram. Lampu merah menyala situasi makin tertekan saat pandemic Covid-19 menjadi hantu ekonomi. Bahkan paling buruk saat pemerintah memberlakukan PSBB (Lamade, 2020).

Sejak disahkannya UU no 40 tahun 2007 tentang perseroan terbatas menjelaskan bahwa ekspatriat tetap boleh jadi direktur utama perusahaan. Direktur utama merupakan pemimpin tertinggi dalam suatu perusahaan dimana secara sekilas merekalah yang menentukan arah perkembangan perusahaan (RI, 2007).

Komisaris Independen pada perusahaan manufaktur berpengaruh negatif dan signifikan terhadap agresivitas pajak perusahaan (Suyanto \& Supramono, 2012). CEO diharapkan dalam memimpin suatu perusahaan bertindak secara professional utamanya dalam melakukan pelaporan pajak.

Corporate Social Responsibility (CSR) merupakan Piramida mencakup total yang merupakan tanggung jawab ekonomi, Legal, Etis dan Filantropis Carrolll menafsirkan perusahaan CSR harus berusaha untuk mencari keuntungan, taat hukun, beretika dan warga Negara yang baik (Huseynov, 2012).

Pajak merupakan salah satu sumber pendapatan Negara yang berasal dari rakyat. Dengan adanya pembayaran pajak maka pemerintah dapat melakukan program program pembangunan yang dapat dinikmati rakyat. Bagi para manajemen perusahaan yang secara umum tidak menginginkan berkurangnya daya beli akan berusaha meminimalkan biaya melalui efisiensi biaya untuk mengoptimalkan laba perusahaan dalam hal ini adalah termasuk pembayaran pajak. Strategi perusahaan dilakukan dengan praktik penghindaran pajak (Pradipta, 2013).

CSR sejalan dengan penguatan berbagai regulasi di dunia Internasional dan ruang lingkup politik. Untuk beberapa nama Sarbanes-Oxley Act (2002) yang menetapkan untuk menghalangi akuntansi fraud dan Global Compact (1999) di AS, semua menyoroti pentingnya manajemen etis dan kegiatan CSR. Mengikuti tren ini organisasi Internasional untuk standardisasi diberlakukan Standar Internasional $26000 \quad$ (ISO 26000) untuk CSR (https:// mukhsonrofi.wordpress.com/2008/09/20/peraturan-atau-undangundang-terkait-fraud-dan-korupsi-sox-sarbanes-oxley-act/).

CSR berpengaruh negatif terhadap tax avoidance. Ini menunjukkan bahwa semakin tinggi tingkat pengungkapan CSR yang dilakukan suatu perusahaan akan menurunkan praktik penghindaran pajak. Capital intensity berpengaruh positif terhadap tax avoidance. Ini menunjukkan bahwa semakin besar intensitas asset tetap suatu perusahaan akan meningkatkan praktek penghindaran pajak (Dharma, 2017).

Apakah CSR berhubungan dengan penghindaran pajak? Pengaruh CSR terhadap Tax avoidance bukti dari kegiatan CSR menguji hubungan empiris awal Interpretasi FASB no 48 (Hoi, 2013).

Beberapa penelitian telah dibuktikan hubungan antara tingkat penghindaran pajak dan kegiatan CSR (Watson, 2015). Secara empiris menunjukkan bahwa perusahaan dengan keterlibatan tinggi dalam CSR dihindari pajak. Mengukur kecenderungan tingkat penghindaran pajak sebagai 
perbedaan antara laba sebelum pajak dan penghasilan kena pajak. Dengan membagi total sampel perusahaan menjadi tiga kelompok dengan nilai CSR tertinggi tidak berbeda secara signifikan dari kelompok menengah mengenai kecenderungan tingkat penghindaran pajak. Namun kelompok dengan nilai CSR terendah menunjukkan kecenderungan yang jauh lebih tinggi untuk menghindari pajak.

Upaya upaya manajemen pajak yang dilakukan oleh wajib pajak untuk meminimisasi beban pajak dapat dilakukan melalui cara tingkat penghindaran pajak. Kategori tingkat penghindaran pajak merupakan tindakan manajemen pajak yang legal karena lebih banyak memanfaatkan celah "Loopholes" yang ada dalam peraturan perpajakan yang berlaku mengutip (Santoso \& Ning, 2013) dalam (Dharma, 2017).

Tindakan perencanaan pajak perusahaan dalam usaha minimisasi penghasilan kena pajak suatu perusahaan baik secara legal atau illegal (Mangoting, 2014) menurut beberapa peneliti tax manajemen (Huseynov, 2012), masalah teori legitimasi (Lanis \& Richardson, 2012), hubungan tingkat penghindaran pajak (Hoi, 2013), corporate governance (Timothy, 2013), performa keuangan (Rahardjo, 2018), CSR (Lau, 2014), index corporate tax avoidance (Huseynov, 2017) merupakan tindakan agresivitas pajak sering juga disebut sebagai tingkat penghindaran pajak menggunakan efektif tax rate.

Penelitian yang dilakukan oleh (Hanlon, 2010) sebelumnya merangkum tentang perpajakan dengan tinjauan penelitian adalah meliputi empat bidang utama yaitu peran pajak penghasilan pada laporan akuntansi keuangan; Tingkat penghindaran pajak perusahaan, Pengambilan keputusan investasi perusahaan, struktur modal dan bentuk organisasi, dan Perpajakan dan harga aset. Setelah skandal Enron dan Worldcom dalam penelitian Hanlon (2005), ini menunjukkan bukti bahwa pendapatan dan bagian dari pendapatan akrual tidak sesuai ketika perusahaan memiliki perbedaan dalam pembukuan pajak, meningkatkan kecurigaan adanya minimalisasi pajak bahwa perusahaan melaporkan sementara pendapatan pajak lebih rendah daripada mereka yang patuh melaporkan lebih besar pada pendapatan pajak dan pengukuran corporate tax avoidance (Salihu, 2013).

Selanjutnya, studi kasus tentang penelitian Starbucks yang dilakukan oleh (Campbell, 2016) mengungkapkan penelitian yang dirancang untuk mengeksplorasi perhitungan dan khususnya praktik minimalisasi pajak harus mempertimbangkan strategi perusahaan dan posisi keseluruhan dalam berbagai kelompok pemangku kepentingan. kegagalan starbucks pada tahun 2012 selama 15 tahun keberhasilannya dalam membayar pajak penghasilan perusahaan di Inggris terkait merancang dan memikirkan implikasi strategis, hukum, etis, dan hubungan masyarakat dari strategi minimalisasi pajak tentang persepsi publik dan strategi perusahaan mengenai minimalisasi pajak (Campbell, 2016).

Terkait dengan karakteristik CEO, penelitian yang dilakukan oleh (Huang, 2013) dalam mengeksplorasi hubungan antara demografi CEO dan konsistensi kinerja CSR di antara perusahaan, penelitian tersebut menunjukkan bahwa kinerja CSR di antara konsistensi peringkat CSR yang diukur dikaitkan dengan administrasi bisnis tingkat master pendidikan MBA, dan ilmu 
pengetahuan M.Sc, gender telah terbukti mempengaruhi kinerja CSR (Huang, 2013).

Penelitian (Zhuang, 2018) meneliti aspek komposisi CEO dampak tentang pengalaman politik, afiliasi akademi, latar belakang pendidikan luar negeri, dan jenis kelamin pada kinerja CSR. Mengenai board member orientasi dan tipe direktur (Ibrahim, 2003), mengenai direktur dalam dan luar direktur board member (Ibrahim \& Angelidis, 1995), Direktur wanita (williams, 2003), Direktur External (Sepulveda, 2014), dan Board Diversity (Cham, 2016).

Dalam pernyataan yang sama, hubungan antara CSR dan studi perpajakan terdapat kesamaan minat di akademisi. Dasar perusahaan memiliki insentif untuk meminimalkan tingkat penghindaran pajak perusahaan, sedikit arus kas keluar. Bahkan sebuah perusahaan tidak menghindari pajak itu sendiri, ia memiliki motivasi meminimalkan pajak dalam perpajakan. Dari penelitian ini, otoritas pajak dapat mengatur perusahaan untuk melibatkan tingkat penghindaran pajak dan mendorong perusahaan melakukan kegiatan CSR (Jeongho Kim, 2017).

Dari latar belakang penelitian, dapat terungkap beberapa formulasi masalah dan penelitian yang akan dilakukan untuk mendapatkan pengembangan hipotesis dan membuktikan apakah CSR dapat memediasi efek karakteristik CEO terhadap tingkat penghindaran pajak dengan variabel yang akan dilakukan oleh pengalaman politik, afiliasi akademi, latar belakang pendidikan luar negeri, dan jenis kelamin. Perumusan masalah berdasarkan latar belakang yang telah dijelaskan sebelumnya dalam penelitian ini yaitu, Apakah CSR memediasi pengaruh pengalaman politik pada tingkat penghindaran pajak, Apakah CSR memediasi pengaruh afiliasi akademi pada tingkat penghindaran pajak, Apakah CSR memediasi pengaruh latar belakang pendidikan di luar negeri pada tingkat penghindaran pajak, dan Apakah CSR memediasi pengaruh jenis kelamin pada tingkat penghindaran pajak.

Dasar teori pemangku kepentingan menyatakan bahwa keberhasilan dan kelangsungan hidup perusahaan sangat tergantung pada kemampuannya untuk menyeimbangkan berbagai kepentingan para pemangku kepentingan. Jika mampu, perusahaan akan mendapatkan dukungan berkelanjutan dan menikmati pangsa pasar yang berkelanjutan dalam pertumbuhan penjualan dan keuntungan juga. Perspektif teori pemangku kepentingan masyarakat dan lingkungan juga merupakan pemangku kepentingan perusahaan yang harus dipertimbangkan (Lako, 2011), dan stakeholder theory (Peterson, 1995.)

Pengalaman politik anggota dewan memiliki pengalaman kerja sebelumnya atau saat ini di lembaga pemerintahan. Pengalaman anggota dewan dalam tata kelola memungkinkan mereka memiliki perkiraan yang lebih baik mengenai penegakan peraturan di masa depan, yang memungkinkan mereka untuk proaktif mengatasi kegiatan CSR (Zhuang, 2018).

Akademi Afiliasi. Para sarjana dari lembaga akademi sebagai pusat penelitian universitas berfungsi di dewan perusahaan sebagai afiliasi akademik independen mempengaruhi kinerja CSR perusahaan karena beberapa alasan (Zhuang, 2018). Hasil penelitian menunjukkan kinerja CSR sebagai pengukuran konsistensi peringkat CSR, terkait dengan spesialisasi pendidikan mereka di master level business administration (MBA) dan science (M.Sc) (Huang, 2013). 
Latar belakang pendidikan luar negeri anggota dewan telah menjadi aspek penting pada komposisi dewan. Dewan memperoleh pengalaman kerja atau pendidikan di luar negeri (Zhuang, 2018).

Jenis kelamin anggota dewan adalah penting untuk tata kelola perusahaan yang efektif (Huang, 2013), direktur wanita (williams, 2003), orientasi dan tipe direktur (Ibrahim, 2003), dan CEO Female (M, 2018).

CSR akan diukur, dikelola pengertian definisi dan interpretasi studi variabel kinerja CSR adalah akuntansi dan kinerja pasar. Kinerja akuntansi terkait dengan hasil keuangan perusahaan. Kinerja pasar terhubung dengan nilai ekuitas dan saham, dua variabel saling terkait. Studi ini telah menggunakan indikator menganalisis hubungan antara kegiatan CSR perusahaan dan nilai pemegang saham menurut Huang, (2013) CSR harus dilihat dalam konteks manajerial memberikan nya adalah untuk bertindak etis, dalam pembangunan ekonomi dan meningkatkan kualitas hidup pekerja, masyarakat lokal, dan masyarakat pada umumnya. Model CSR piramida total CSR merupakan tanggung jawab ekonomis, hukum, etis dan filantropi, carol menafsirkan perusahaan CSR harus mendorong untuk membuat keuntungan, mematuhi hukum, etis, dan menjadi warga perusahaan yang baik (Huseynov, 2012); Pengungkapan CSR (Laksmi, 2018), Dampak karakteristik dewan direksi (Setiawan, 2018), Kode Etik (Rodriguez-Dominguez, 2009), External Direktur (Sepulveda, 2014), corporate governance (Timothy, 2013), komposisi direktur (Zhuang, 2018), corporate board (Zhang, 2016), ownership structure (M.Al-Bassam, 2018).

Konsep tarif penghindaran pajak penelitian sebelumnya mendefinisikan tarif penghindaran pajak sebagai konsep minimalisasi pajak. Penghematan pajak konsep yang sama adalah konsep yang lebih luas daripada tarif penghindaran pajak, menawarkan kembali kegiatan pengurangan pajak yang legal dan rasional, sedangkan penghindaran pajak mengacu pada kegiatan ilegal termasuk penipuan, pengecualian keuntungan dan pengakuan biaya yang berlebihan. Dengan kata lain tingkat penghindaran pajak dan penghematan pajak, serta sebagian besar terkait dengan kegiatan yang tidak sesuai dengan tujuan undangundang pajak (Jeongho Kim, 2017).

Berdasarkan keragka penelitian berisi prediksi sementara tentang masalah yang diangkat dalam penelitian ini. Pengembangan hipotesis yang akan diajukan dalam penelitian ini, Hipotesis penelitian $\left(\mathrm{H}_{1}\right)$ CSR memediasi pengaruh pengalaman politik terhadap tingkat penghindaran pajak, Hipotesis $\left(\mathrm{H}_{2}\right)$, CSR memediasi pengaruh afiliasi akademi terhadap tingkat penghindaran pajak. Hipotesis $\left(\mathrm{H}_{3}\right)$, CSR memediasi pengaruh latar belakang pendidikan di luar negeri terhadap tingkat penghindaran pajak. Hipotesis $\left(\mathrm{H}_{4}\right)$, CSR memediasi pengaruh jenis kelamin terhadap tingkat penghindaran pajak. Kerangka konseptual penelitian dapat digambarkan sebagai berikut beberapa sumber graphics and guidelines for theory-consistent empirical research (Luft, 2003), research methodology (proffesional, 2012), fundamental of research and statistics (Yogesh, 2006), Research methodology: tools and technique (Pandey, 2015). 


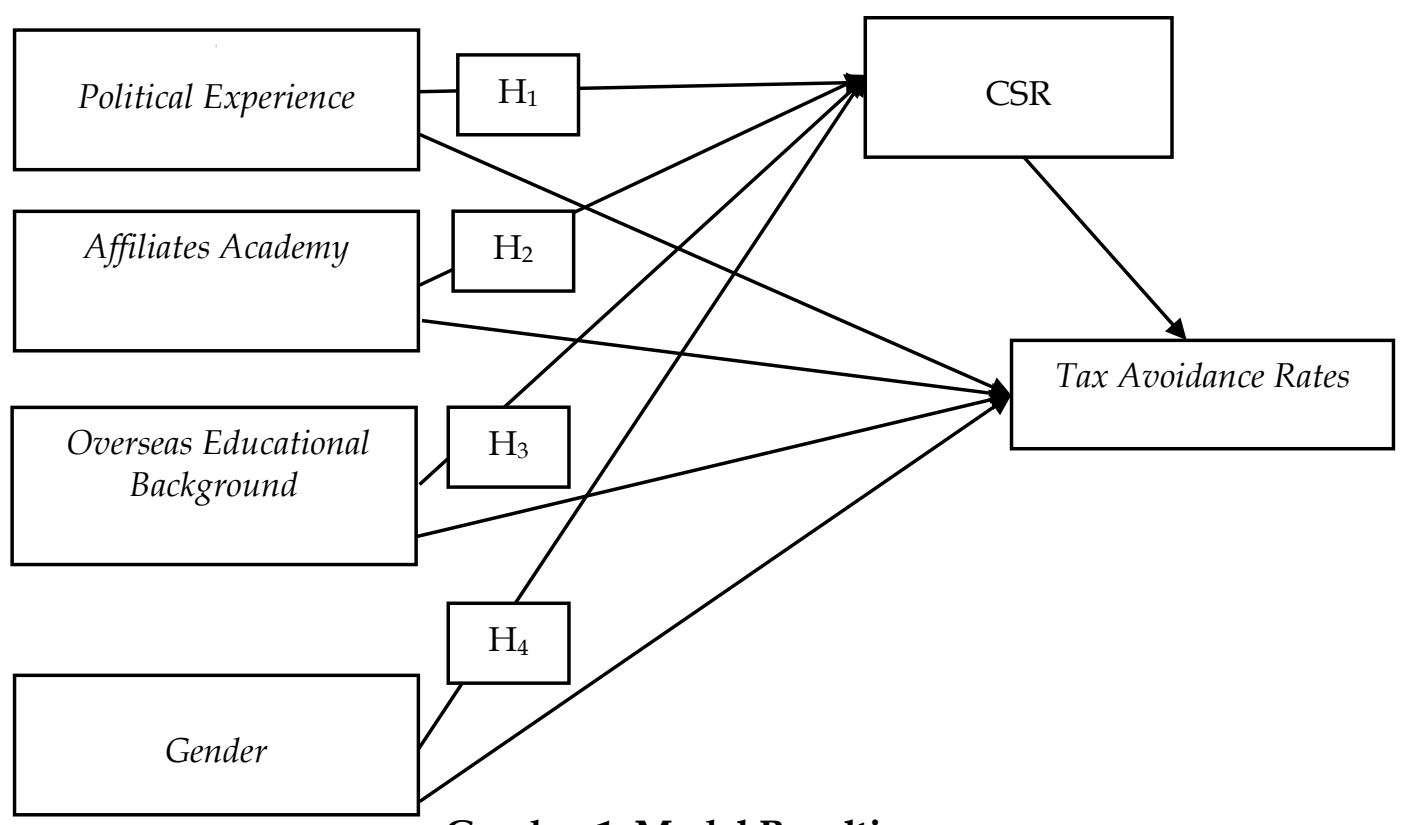

Gambar 1. Model Peneltian

Sumber: Hartono, 2006

\section{METODE PENELITIAN}

Model Analisis. Tentukan persamaan struktural untuk menstandarkan data yang digunakan dalam penelitian, sehingga semua variabel dapat diukur $\mathrm{PE}=$ Pengalaman Politik. AA $=$ Afiliasi Akademi $\mathrm{OB}=$ Latar Belakang Pendidikan Luar Negeri. $\mathrm{G}=$ Gender CSR $=$ Tanggung jawab sosial perusahaan TPP $=$ Tax Avoidance Rate Lev $=$ Leverage $B a=$ jalan koefisien $\mathrm{E}=$ Error

Jenis Penelitian adalah asosiasi kausalitas kuantitatif untuk melihat hubungan sebab akibat antara satu variabel dan variabel lainnya. Penelitian kuantitatif adalah metodologi penelitian yang berusaha untuk mengukur data, dan biasanya beberapa bentuk analisis statistik. Oleh karena itu, penelitian ini akan melakukan beberapa perhitungan statistik untuk mendapatkan hasil penelitian. Penelitian dilakukan terhadap perusahaan manufaktur yang tercatat di Bursa Efek Indonesia 2017-2018.

Metode Pemrosesan dan Analisis Data menggunakan model analisis jalur dengan perangkat lunak aplikasi SPSS. Teknik analisis data dilakukan dalam langkah-langkah berikut, Membuat model persamaan struktural untuk menjelaskan hubungan sebab akibat antara variabel. Dalam penelitian ini menggunakan persamaan model berikut, Model persamaan yang menjelaskan efek variabel independen dan variabel mediasi pada variabel dependen. Model persamaan model analisis jalur dan menguji hipotesis menggunakan program perangkat lunak SPSS (Sarwono, 2007).

Variabel Independen penelitian pengalaman politik adalah posisi tertinggi di perusahaan dengan latar belakang Pengalaman Politik. pengalaman politik mengacu pada pengalaman kerja saat ini di lembaga pemerintahan. Diukur siapa yang memiliki pengalaman politik. Pengalaman politik keluar ketika telah menjabat atau saat ini bekerja posisi dalam pemerintahan. Alat ukur 
PPCEO = EXij EXij; Variabel dummy, 1 Jika item memiliki koneksi politik dan 0 lainnya Jika item tidak memiliki koneksi politik.

Afiliasi akademi adalah tingkat pendidikan SMP, SMA, Diploma, BA, Mba, Msc, dan Phd pada sarjana umum dari lembaga akademik universitas dan pusat penelitian yang bekerja di perusahaan. Diukur sebagai afiliasi akademis. Afiliasi akademik ada ketika bekerja dalam posisi di lembaga penelitian. Alat Ukur $\mathrm{AACEO}=\mathrm{EXijEXij}$; Nilai tingkat pendidikan: $1=\mathrm{SMP} ; 2=\mathrm{SMA} ; 3=$ diploma; 4 = BA; $5=$ Mba, Msc; $6=$ Phd.

Latar belakang pendidikan luar negeri adalah aspek penting mendapatkan pekerjaan atau pengalaman latar belakang pendidikan di luar negeri. Pengalaman latar belakang pendidikan di luar negeri memberikan pandangan yang beragam kepada perusahaan. Pengalaman latar belakang pendidikan luar negeri menunjukkan pengaruh positif terkait kinerja CSR. Diukur yang memiliki latar belakang pendidikan luar negeri, itu didefinisikan sebagai pengalaman kerja atau pendidikan di luar negeri LBACEO = EXij; EXij; Dummy variabel: 1 Jika item memiliki latar belakang Pendidikan Luar Negeri dan 0 lainnya jika item tidak memiliki latar belakang pendidikan luar negeri.

Jenis kelamin adalah jenis kelamin di antara yang penting untuk tata kelola perusahaan yang efektif. Diukur sebagai Jenis kelamin adalah perempuan. $\mathrm{KJKCEO}=$ EXijEXij; Variabel dummy: 1 jika item Jenis kelamin adalah Perempuan dan 0 Jika jenis kelamin adalah laki-laki

Variabel Dependen penelitian adalah tingkat penghindaran pajak yaitu perbedaan pajak, selisih bisa dihasilkan dari peningkatan laba atau penurunan pajak dari tariff penghindaran pajak. Dengan demikian, peneliti menyimpulkan perbedaan pajak dapat digunakan sebagai proxy untuk tarif penghindaran pajak. Diukur oleh BTD, (Jeongho Kim, 2017) menyarankan perkiraan tarif penghindaran pajak berdasarkan pajak buku yang berbeda. Perkiraan tingkat Penghindaran Pajak Perusahaan Tsi, $\mathrm{t}=\mathrm{T}, \mathrm{t}$

$\mathrm{BTD}=($ Laba sebelum pajak - penghasilan kena pajak $)$

Total Aset

Variabel Mediasi penelitian CSR diukur dengan indeks CSR. Akan diberikan nilai satu jika kegiatan CSR tertentu diungkapkan dan nol jika barang tidak diungkapkan, Indikator Item yang digunakan sebagai pengukuran disesuaikan dengan Global Reporting Initiative G4 rumus perhitungan diberikan sebagai berikut, skala 0-91 untuk mengukur kinerja CSR. CSRDIi = E Xij, Ni; CSRDIj: CSR disclousure index untuk perusahaan. Ni, apa yang anda ni <90; Xij: Dummy variabel: 1 Jika item pengungkapan dan 0 lainnya jika item tidak ada pengungkapan.

Perusahaan Manufaktur memenuhi kriteria Kriteria yang ditetapkan pada sampel ini a. Perusahaan Manufaktur yang listing b. Perusahaan Manufaktur yang menerbitkan laporan tahunan keuangan c. Perusahaan yang memiliki kelengkapan data penelitian. Metode pengumpulan data dari laporan keuangan dan laporan tahunan perusahaan publik pada BEI periode 2017-2018 dengan perusahaan manufaktur yang menjadi subjek penelitian. Prosedur pengumpulan data yang digunakan dalam penelitian ini (Hartono, 2006) menggunakan metode studi kepustakaan untuk menemukan dan mengumpulkan data dari literatur, makalah ilmiah, jurnal ekonomi, dan materi 
lain yang berkaitan dengan penelitian yang dilakukan. Pendataan dilakukan untuk mendapatkan data yang dibutuhkan yang dikumpulkan dalam penelitian yang diperoleh dari berbagai sumber. Studi sampel penelitian perusahaan manufaktur yang terdaftar di IDX 2017-2018, 632 perusahaan yang terdaftar terdapat perusahaan manufaktur sejumlah 179 perusahaan dan perusahaan manufaktur 113 yang menerbitkan laporan keuangan dan 66 perusahaan manufaktur tidak menerbitkan laporan keuangan. Perusahaan manufaktur yang memenuhi kriteria ditetapkan dalam sampel penelitian, Perusahaan manufaktur yang terdaftar, dan Perusahaan manufaktur yang menerbitkan laporan keuangan tahunan. Perusahaan yang memiliki data penelitian lengkap.

\section{HASIL DAN PEMBAHASAN}

Statistik deskriptif digunakan untuk memberikan informasi mengenai variabel variabel penelitian seperti tingkat penghindaran pajak, CSR, Pengalaman politik, Akademi Afiliasi, Latar belakang pendidikan di luar negeri dan Jenis Kelamin. Informasi yang dapat disediakan oleh statistic deskriptif antara lain nilai terendah, nilai tertinggi, nilai tengah dan standar deviasi' Pengujian statistic deskriptif dilakukan menggunakan SPSS. Diskripsi keseluruhan variabel penelitian disajikan pada Tabel 1, berikut ini.

Tabel 1. Descriptives \& Frekuensi

\begin{tabular}{|c|c|c|c|c|c|}
\hline & $\mathrm{N}$ & Minimum & Maximum & Mean & Std. Deviation \\
\hline $\begin{array}{l}\text { Penghindaran } \\
\text { Pajak }\end{array}$ & 179 & .0001 & .3626 & . 083198 & - 0721954 \\
\hline CSR & 179 & .0220 & 2967 & 126036 & .0622863 \\
\hline $\begin{array}{l}\text { Political } \\
\text { Experience }\end{array}$ & 179 & 0 & 1 & .51 & .501 \\
\hline $\begin{array}{l}\text { Academic } \\
\text { Affiliation }\end{array}$ & 179 & 1 & 6 & 4.29 & .824 \\
\hline $\begin{array}{l}\text { Overseas } \\
\text { Educational }\end{array}$ & 179 & 0 & 1 & .68 & 469 \\
\hline $\begin{array}{l}\text { Background } \\
\text { Gender }\end{array}$ & $\begin{array}{l}179 \\
179\end{array}$ & 0 & 1 & .08 & 269 \\
\hline Valid N (listwise) & 179 & & & & \\
\hline
\end{tabular}

Sumber: Data Penelitian, 2020

Pada Tabel 1, ditunjukkan bahwa statistic deskriptif untuk variabel tingkat penghindaran pajak memiliki nilai minimum sebesar 0,0001 dan nilai maximum sebesar 0,3626. Nilai rata - rata variabel tingkat penghindaran pajak adalah sebesar 0,083198. Hal ini berarti bahwa rata - rata tingkat penghindaran pajak sebesar 0,083198. Standar deviasi sebesar 0,0721954 menunjukkan bahwa batas penyimpangan variabel tingkat penghindaran pajak adalah sebesar 0,0721954.

Hasil pengujian statistik deskriptif untuk variabel CSR memiliki nilai minimum sebesar 0,0220 dan nilai maximum sebesar 0,2967. Nilai rata - rata untuk variabel CSR adalah sebesar 0,126036. Hal ini berarti bahwa secara rata rata variabel CSR 0,126036. Standar deviasi sebesar 0,0622863 menggambarkan bahwa batas penyimpangan variabel CSR 0,0622863.

Hasil pengujian statistik deskriptif untuk variabel pengalaman politik CEO memiliki nilai minimum sebesar 0 dan nilai maximum sebesar 1 . Nilai rata - rata untuk variabel Pengalaman politik adalah sebesar 0,51. Hal ini berarti bahwa 
secara rata - rata variabel Pengalaman politik 0,51. Standar deviasi sebesar 0,501 menggambarkan bahwa batas penyimpangan variabel pengalaman politik 0,501.

Hasil pengujian statistik deskriptif untuk variabel afiliasi akademi memiliki nilai minimum sebesar 1 dan nilai maximum sebesar 6. Nilai rata - rata untuk variabel afiliasi akademi adalah sebesar 4,29. Hal ini berarti bahwa secara rata rata variabel afiliasi akademi 4,29 standar deviasi sebesar 0,824 menggambarkan bahwa batas penyimpangan variabel afiliasi akademi 0,824 .

Hasil pengujian statistik deskriptif untuk variabel jenis kelamin memiliki nilai minimum sebesar 0 dan nilai maximum sebesar 1 . Nilai rata - rata untuk variabel jenis kelamin adalah sebesar 0,08. hal ini berarti bahwa secara rata - rata variabel jenis kelamin 0,08. Standar deviasi sebesar 0,269 menggambarkan bahwa batas penyimpangan variabel jenis kelamin 0,269.

Hasil pengujian statistik deskriptif untuk variabel latar belakang pendidikan di luar negeri memiliki nilai minimum sebesar 0 dan nilai maximum sebesar 1 . Nilai rata - rata untuk variabel latar belakang pendidikan di luar negeri adalah sebesar 0,68. Hal ini berarti bahwa secara rata - rata variabel latar belakang pendidikan di luar negeri 0,68. Standar deviasi sebesar 0,469 menggambarkan bahwa batas penyimpangan variabel latar belakang pendidikan di luar negeri 0,469. Hasil dari perhitungan SPSS terangkum dalam Tabel 2, sebagai berikut.

Tabel 2. Hasil Path Analysis Model 1

\begin{tabular}{lccc}
\hline Model & $\begin{array}{c}\text { Unstandardized } \\
\text { Coefficients }\end{array}$ & $\mathrm{t}$ & Sig. \\
\cline { 2 - 3 } & $\mathrm{B}$ & & \\
\hline (Constant) & .056 & 2.321 & .021 \\
$\quad$ Political Experience & .022 & 2.269 & .025 \\
1 Academic Affiliation & .015 & 2.605 & .010 \\
Overseas Educational Background & -.005 & -.432 & .666 \\
Gender & -.038 & -2.259 & .025 \\
\hline
\end{tabular}

a. $\quad$ Dependent Variable: CSR

Sumber: Data Penelitian, 2020

Berdasarkan hasil uji path analisis, model 1 dan model 2 dijelaskan pada masing masing gambar uji analisis. Analisis jalur digunakan dalam penelitian ini. Hasil dari perhitungan SPSS terangkum dalam Tabel 3, sebagai berikut.

Tabel 3. Path Analysis Model 2

\begin{tabular}{|c|c|c|c|c|}
\hline \multicolumn{2}{|c|}{ Model } & $\begin{array}{c}\begin{array}{c}\text { Unstandardized } \\
\text { Coefficients }\end{array} \\
\text { B }\end{array}$ & $\mathrm{t}$ & Sig. \\
\hline \multirow{6}{*}{2} & (Constant) & .050 & 1.716 & .088 \\
\hline & Political Experience & -.013 & -1.144 & .254 \\
\hline & Academic Affiliation & .002 & .342 & .732 \\
\hline & $\begin{array}{l}\text { Overseas Educational } \\
\text { Background }\end{array}$ & -.005 & -.406 & .685 \\
\hline & Gender & .015 & .725 & .469 \\
\hline & CSR & .255 & 2.834 & .005 \\
\hline
\end{tabular}

a. Dependent Variable: Penghindaran Pajak

Sumber: Data Penelitian, 2020

Hasil tes statistik koefisien penentuan ( $\mathrm{R}$ square). Berdasarkan hasil $\mathrm{R}$ square disesuaikan untuk 2 model, jika perbandingan koefisien penentuan dibuat, 
ditemukan hasil uji model 1 bahwa nilai $\mathrm{R}$ square lebih besar dari $\mathrm{R}$ square nilai model 2, yang 0,095 > 0,053. Dengan demikian disimpulkan bahwa CSR adalah variabel mediasi yang tepat untuk memediasi tingkat penghindaran pajak.

Tabel 4. Koefisien Determinasi (R square)

\begin{tabular}{ccc}
\hline Model & R Square & R Square Adj \\
\hline 1 & 0.095 & 0.074 \\
2 & 0.053 & 0.026 \\
\hline
\end{tabular}

Sumber: Data Penelitian, 2020

Diskusi analisis jalur dalam penelitian ini dilakukan dengan menggunakan bantuan SPSS CSR memediasi efek pengalaman politik terhadap tingkat penghindaran pajak. $\mathrm{H}_{1}$ menyatakan bahwa CSR sebagai variabel mediasi efek pengalaman politik pada tingkat penghindaran pajak diuji oleh analisis jalur dengan tes tunggal. Analisis jalur untuk menguji CSR sebagai mediasi efek pengalaman politik pada tingkat penghindaran pajak adalah hasil penelitian dari tes analisis jalur yang memberikan nilai koefisien regresi dan kesalahan standar antara variabel. Gambar hasil uji path analisis, diketahui bahwa efek variabel independen (x), yaitu pengalaman politik pada CSR sebagai variabel mediasi atau disebut koefisien a, adalah 0,022 , dengan kesalahan standar (sa) 0,010, sementara variabel mediasi CSR pada variabel dependen adalah tingkat penghindaran pajak atau disebut koefisien. $b$ adalah 0,25 dengan kesalahan standar 0,090. Hasil dari perhitungan SPSS terangkum dalam Tabel 3, sebagai berikut. Apakah ada efek tidak langsung dari CSR berdasarkan analisis jalur, tes tunggal dapat digunakan. Berdasarkan kesalahan standar efek tidak langsung, hasilnya adalah 0,012.

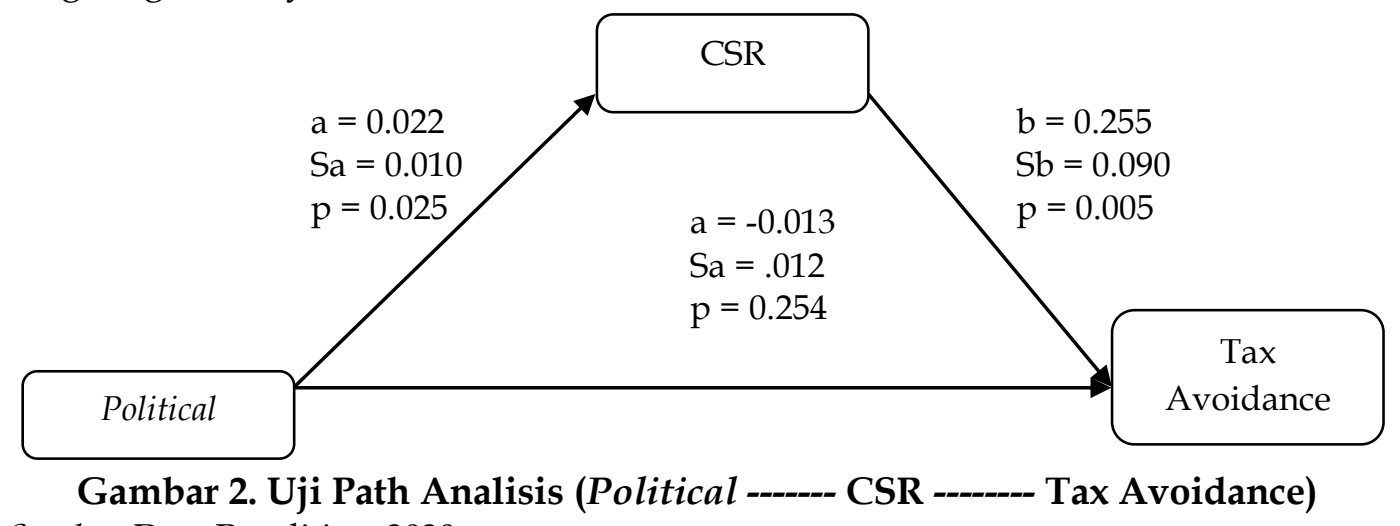

Sumber: Data Penelitian, 2020

Signifikansi pengaruh tidak langsung pengalaman politik terhadap tingkat penghindaran pajak melalui CSR diuji dengan cara menghitung nilai $\mathrm{T}$ dari koefisien ab dengan rumus sebagai berikut.

$$
\begin{aligned}
& t_{1}=\frac{a \cdot b}{\sqrt{b^{2} S a^{2}+a^{2} S b^{2}}} \\
& =\frac{0,022 \cdot 0,255}{\sqrt{\left(0,522^{2} 0,01^{2}\right)+\left(0,022^{2} 0,09^{2}\right)}} \\
& =\frac{0,0561}{0,003}=1,737
\end{aligned}
$$


Berdasarkan perhitungan, diperoleh nilai t-hitung sebesar 1,737 > nilai $p$ hitung 0,082

Tabel 5. Hasil Uji Hipotesis

\begin{tabular}{ccccc}
\hline & Hipotesis & Koefisien & t-value & $p$-value \\
\hline $\mathrm{H}_{1}$ & $\begin{array}{l}\text { Pengelaman Politik } \rightarrow \text { CSR } \rightarrow \\
\text { tingkat pengindaran pajak }\end{array}$ & 0,056 & 1,737 & 0,082 \\
\hline Sumber: & Data Penelitian, 2020 & & \\
\hline
\end{tabular}

Pentingnya pengaruh tidak langsung dari pengalaman politik terhadap tingkat penghindaran pajak melalui CSR diuji dengan menghitung nilai $t$ koefisien ab p 0,254 berdasarkan perhitungan di atas, hitungan $t$ adalah 0,254> 0,082 sehingga ada efek tidak langsung yang signifikan dari pengalaman politik pada tingkat penghindaran pajak melalui variabel mediasi CSR.

Hasil ini menunjukkan bahwa CSR mampu menjadi mediasi antara efek pengalaman politik pada tingkat penghindaran pajak sebagaimana dibuktikan oleh hasil tes tunggal. Pengaruh mediasi kuat dan kemudian ada $\mathrm{H}_{1}$ menyatakan bahwa CSR mampu menjadi mediasi antara efek pengalaman politik pada tingkat penghindaran pajak didukung. Pengalaman politik, CSR, dan tingkat penghindaran pajak berdasarkan analisis Jalur menggunakan Tes Sobel menunjukkan bahwa CSR dapat memediasi antara pengalaman politik dan tingkat penghindaran pajak. Hasil penelitian ini menunjukkan pengalaman politik sebagai efek antara karakteristik CEO tata kelola perusahaan, masyarakat umum, dan tingkat penghindaran pajak adalah bahwa CSR dapat memediasi tingkat penghindaran pajak.

CSR memediasi efek afiliasi akademi terhadap tingkat penghindaran pajak. $\mathrm{H}_{2}$ menyatakan bahwa CSR sebagai variabel mediasi efek afiliasi akademi pada tingkat penghindaran pajak diuji dengan analisis jalur dengan satu tes. Analisis jalur untuk menguji CSR sebagai mediasi efek afiliasi akademi pada tingkat penghindaran pajak. Hasil menunjukkan uji analisis jalur yang memberikan nilai koefisien regresi dan kesalahan standar antara variabel. Berdasarkan gambar hasil uji path analisis, diketahui bahwa efek variabel independen (x), yaitu afiliasi akademi pada CSR sebagai variabel mediasi atau disebut koefisien a, adalah 0,015 dengan kesalahan standar (sa) 0,006, sedangkan variabel mediasi CSR pada variabel dependen adalah tingkat penghindaran pajak atau koefisien. $\mathrm{b}$ adalah 0,25 dengan kesalahan standar 0,090. Apakah ada efek tidak langsung dari CSR berdasarkan analisis jalur di atas, tes tunggal dapat digunakan. Berdasarkan kesalahan standar, efek tidak langsung adalah 0,007.

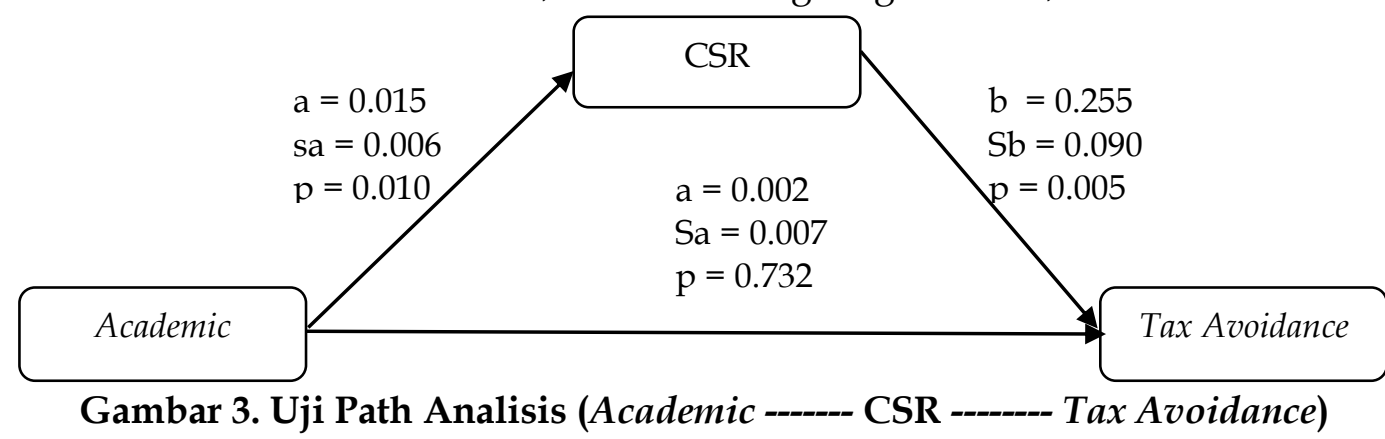

Sumber: Data Penelitian, 2020 
Signifikansi pengaruh tidak langsung afiliasi akademi terhadap tingkat penghindaran pajak melalui CSR diuji dengan cara menghitung nilai $\mathrm{T}$ dari koefisien ab dengan rumus sebagai berikut.

$$
\begin{aligned}
& t_{2}=\frac{a \cdot b}{\sqrt{b^{2} S a^{2}+a^{2} S b^{2}}} \\
& =\frac{0,015 \cdot 0,255}{\sqrt{\left(0,255^{2} 0,006^{2}\right)+\left(0,015^{2} 0,09^{2}\right)}} \\
& =\frac{0,003825}{0,00204}=1,874
\end{aligned}
$$

Berdasarkan perhitungan, diperoleh nilai t-hitung sebesar $1,874>$ nilai $\mathrm{p}$ hitung 0,060.

Tabel 6. Hasil Uji Hipotesis

\begin{tabular}{llcccc}
\hline & Hipotesis & Koefisien & t-value & p-value \\
\hline $\mathrm{H}_{2}$ & $\begin{array}{l}\text { Akademi } \\
\text { tingkat pengindaran pajak }\end{array}$ & & 0,003 & 1,874 & 0,060 \\
& & & \\
\hline
\end{tabular}

Sumber: Data Penelitian, 2020

Pentingnya efek tidak langsung dari afiliasi akademik pada tingkat penghindaran pajak melalui CSR diuji dengan menghitung nilai $t$ koefisien ab $\mathrm{p}$ 0,732 berdasarkan perhitungan di atas, hitungan $t$ adalah $0,732>0,060$ sehingga ada efek tidak langsung yang signifikan dari afiliasi akademi pada tingkat penghindaran pajak melalui variabel mediasi CSR.

Hasil ini menunjukkan bahwa CSR mampu menjadi mediasi antara efek afiliasi akademis pada tingkat penghindaran pajak sebagaimana dibuktikan oleh hasil tes tunggal. Pengaruh mediasi kuat dan kemudian ada hipotesis (ii) Menyatakan bahwa CSR mampu menjadi mediasi antara efek afiliasi akademi pada tingkat penghindaran pajak didukung. Afiliasi akademik, CSR, dan tingkat penghindaran pajak berdasarkan analisis jalur menggunakan Tes Sobel menunjukkan bahwa CSR dapat memediasi efek antara Afiliasi akademik dan tingkat penghindaran pajak. Hasil penelitian ini menunjukkan afiliasi akademi sebagai pengaruh antara karakteristik CEO tata kelola perusahaan, masyarakat pada tingkat penghindaran pajak adalah bahwa CSR dapat memediasi pada tingkat penghindaran pajak.

CSR memediasi efek latar belakang pendidikan di luar negeri terhadap tingkat penghindaran pajak. Hipotesis (iii). latar belakang pendidikan di luar negeri ------ CSR ------- tingkat penghindaran pajak. Hipotesis (iii) Menyatakan bahwa CSR sebagai variabel mediasi efek latar belakang pendidikan luar negeri pada tingkat penghindaran pajak diuji dengan analisis jalur dengan tes sobel. Analisis jalur untuk menguji CSR sebagai mediasi efek latar belakang pendidikan luar negeri pada tingkat penghindaran pajak.Hasil tes analisis jalur yang memberikan nilai koefisien regresi dan kesalahan standar antara variabel. Berdasarkan gambar hasil uji path analisis, diketahui bahwa efek variabel independen (x), yaitu latar belakang pendidikan luar negeri pada CSR sebagai variabel mediasi atau disebut koefisien a, adalah -0,005 dengan kesalahan standar (sa) 0,011, sementara variabel mediasi CSR pada variabel dependen adalah tingkat penghindaran pajak yang disebut koefisien b senilai 0,255 dengan 
kesalahan standar 0,090. Apakah ada efek tidak langsung dari CSR berdasarkan analisis jalur di atas, tes tunggal dapat digunakan. Berdasarkan kesalahan standar efek tidak langsung, hasilnya adalah 0,013 .

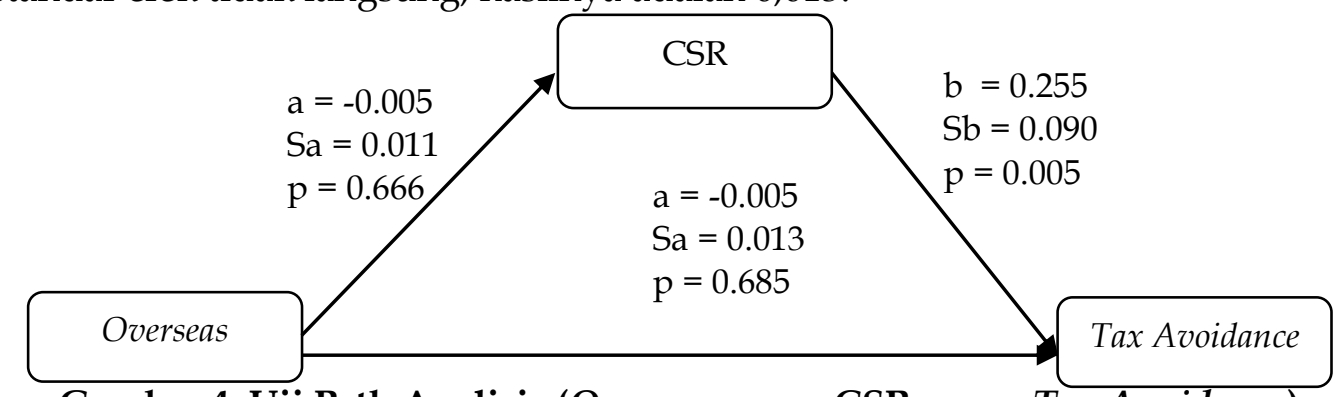

Gambar 4. Uji Path Analisis (Overseas ---_-- CSR --_--- Tax Avoidance)

Sumber: Data Penelitian, 2020

Signifikansi pengaruh tidak langsung latar belakang pendidikan di luar negeri terhadap tingkat penghindaran pajak melalui CSR diuji dengan cara menghitung nilai $\mathrm{T}$ dari koefisien ab dengan rumus sebagai berikut.

$$
\begin{aligned}
& t_{3}=\frac{a \cdot b}{\sqrt{b^{2} S a^{2}+a^{2} S b^{2}}} \\
& =\frac{-0,005 \cdot 0,255}{\sqrt{\left(0,255^{2} 0,011^{2}\right)+\left(-0,005^{2} 0,09^{2}\right)}} \\
& =\frac{-0,00127}{0,00284}=-0,448
\end{aligned}
$$

Berdasarkan perhitungan, diperoleh nilai t-hitung sebesar $-0,448<$ nilai $p$ hitung 0,653

Tabel 7. Hasil Uji Hipotesis

\begin{tabular}{llccc}
\hline \multicolumn{1}{c}{ Hipotesis } & Koefisien & t-value & p-value \\
\hline $\mathrm{H}_{3}$ & $\begin{array}{l}\text { Latar belakang pendidikan di } \\
\text { luar negeri } \rightarrow \text { CSR } \rightarrow \text { tingkat } \\
\text { pengindaran pajak }\end{array}$ & $-0,001$ & $-0,448$ & 0,653 \\
& & & \\
\hline
\end{tabular}

Sumber: Data Penelitian, 2020

Pentingnya pengaruh tidak langsung latar belakang pendidikan luar negeri terhadap tingkat penghindaran pajak melalui CSR diuji dengan menghitung nilai t koefisien AB P sebesar 0,685 berdasarkan perhitungan di atas, diperoleh $\mathrm{t}$ count sebesar 0,685>0,653 sehingga terdapat efek tidak langsung yang signifikan dari latar belakang pendidikan luar negeri tentang tingkat penghindaran pajak melalui variabel mediasi CSR.

Hasil ini menunjukkan bahwa CSR mampu menjadi mediasi antara efek latar belakang pendidikan luar negeri pada tingkat penghindaran pajak sebagaimana dibuktikan dengan hasil tes sobel. Pengaruh Mediasi kuat dan kemudian ada hipotesis (iii) Menyatakan bahwa CSR mampu menjadi mediasi antara efek latar belakang pendidikan luar negeri pada tingkat penghindaran pajak didukung. latar belakang pendidikan luar negeri, CSR, dan tingkat penghindaran pajak berdasarkan analisis jalur menggunakan tes Sobel menunjukkan bahwa CSR dapat memediasi efek antara latar belakang pendidikan di luar negeri dan tingkat penghindaran pajak. Hasil penelitian ini menunjukkan bahwa latar belakang pendidikan di luar negeri sebagai pengaruh 
antara karakteristik CEO tata kelola perusahaan; masyarakat dan keragaman pada tingkat penghindaran pajak adalah bahwa CSR sangat mungkin untuk memediasi tingkat penghindaran pajak.

CSR memediasi efek jenis kelamin terhadap tingkat penghindaran pajak. Hipotesis (iv). Jenis kelamin ------ CSR ------ tingkat penghindaran pajak. Hipotesis (iv) Menyatakan bahwa CSR sebagai variabel mediasi efek jenis kelamin terhadap tingkat penghindaran pajak diuji oleh analisis jalur dengan tes tunggal. Analisis jalur untuk menguji CSR sebagai mediasi efek jenis kelamin pada tingkat penghindaran pajak.

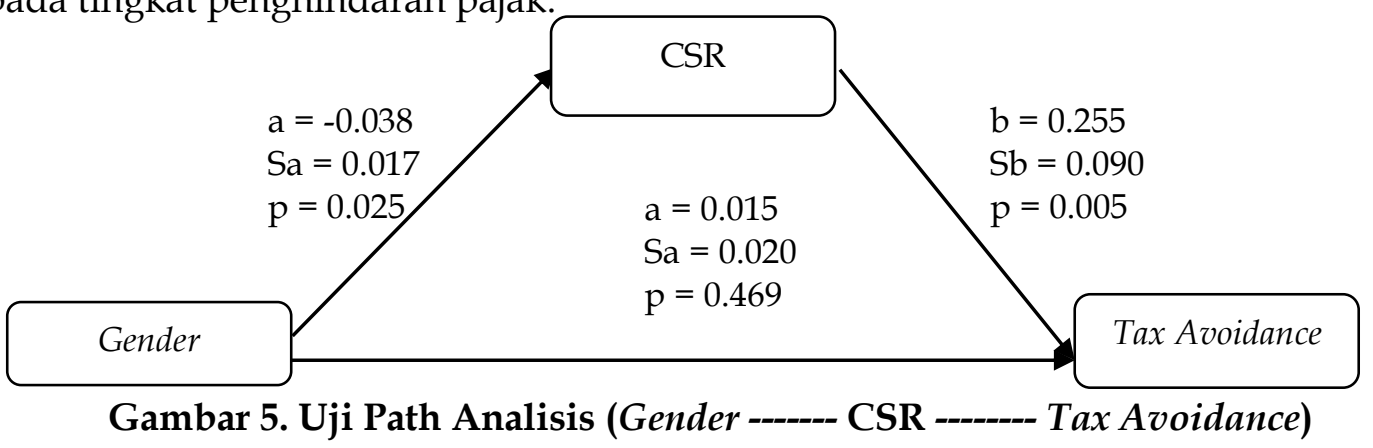

Sumber: Data Penelitian, 2020

Signifikansi pengaruh tidak langsung jenis kelamin terhadap tingkat penghindaran pajak melalui CSR diuji dengan cara menghitung nilai $\mathrm{T}$ dari koefisien ab dengan rumus berikut ini.

$$
\begin{aligned}
& t_{4}=\frac{a \cdot b}{\sqrt{b^{2} S a^{2}+a^{2} S b^{2}}} \\
& =\frac{-0,038 \cdot 0,255}{\sqrt{\left(0,255^{2} 0,017^{2}\right)+\left(-0,038^{2} 0,09^{2}\right)}} \\
& =\frac{-0,00969}{0,005521}=-1,754
\end{aligned}
$$

Berdasarkan perhitungan diatas, diperoleh nilai t-hitung sebesar $-1,754<$ nilai $\mathrm{p}$ hitung 0,079 .

Tabel 8. Hasil Uji Hipotesis

\begin{tabular}{llccc}
\hline & Hipotesis & Koefisien & t-value & p-value \\
\hline $\mathrm{H}_{4}$ & $\begin{array}{l}\text { Jenis kelamin } \rightarrow \text { CSR } \rightarrow \text { tingkat } \\
\text { pengindaran pajak }\end{array}$ & $-0,009$ & $-1,754$ & 0,079 \\
\hline
\end{tabular}

Sumber: Data Penelitian, 2020

Hasil menunjukkan uji analisis jalur yang memberikan nilai koefisien regresi dan kesalahan standar antara variabel. Berdasarkan gambar hasil uji path analisis, diketahui bahwa efek variabel independen (x), yaitu jenis kelamin, pada CSR sebagai variabel mediasi atau disebut koefisien a adalah -0,038 dengan kesalahan standar (sa) 0,017, sementara variabel mediasi CSR pada variabel dependen, yaitu tingkat penghindaran pajak, disebut sebagai koefisien b 0,255 dengan kesalahan standar 0,090. Apakah ada efek tidak langsung dari CSR berdasarkan analisis jalur di atas, tes tunggal dapat digunakan. Berdasarkan kesalahan standar efek tidak langsung, hasilnya adalah 0,020. Signifikansi efek tidak langsung jenis kelamin pada tingkat penghindaran pajak melalui CSR diuji dengan menghitung nilai $\mathrm{t}$ koefisien ab p 0,469 berdasarkan perhitungan di atas, hitungan $t$ adalah 0,469 $>0,079$ sehingga ada efek tidak langsung yang signifikan dari jenis kelamin pada tingkat penghindaran pajak melalui variabel mediasi 
CSR. Hasil ini menunjukkan bahwa CSR mampu menjadi mediasi antara efek jenis kelamin pada tingkat penghindaran pajak sebagaimana dibuktikan oleh hasil tes sobel. Pengaruh mediasi kuat dan ada hipotesis (iv). Menyatakan bahwa CSR mampu menjadi mediasi antara efek jenis kelamin pada tingkat penghindaran pajak didukung. jenis kelamin, CSR, dan tingkat penghindaran pajak berdasarkan Analisis Jalur menggunakan Tes Sobel menunjukkan bahwa CSR dapat memediasi efek antara jenis kelamin dan tingkat penghindaran pajak. Hasil penelitian ini menunjukkan bahwa jenis kelamin sebagai pengaruh antara karakteristik CEO masyarakat tata kelola perusahaan pada tingkat penghindaran pajak adalah bahwa CSR dapat memediasi tingkat penghindaran pajak.

\section{SIMPULAN}

Kesimpulan yang diperoleh dari penelitian ini adalah Hipotesis pertama, CSR dapat memediasi pengaruh pengalaman politik terhadap tingkat penghindaran pajak. Hipotesis kedua, CSR dapat memediasi pengaruh afiliasi akademi terhadap tingkat penghindaran pajak. Hipotesis ketiga, CSR dapat memediasi pengaruh latar belakang pendidikan di luar negeri terhadap tingkat penghindaran pajak. Hipotesis keempat, CSR dapat memediasi pengaruh jenis kelamin terhadap tingkat penghindaran pajak.

\section{REFERENSI}

Ayu Chairina laksmi, Z. k. (2018). The Effect of GCG and earning management to CSR disclosure. Academy of Accounting and Financial Studies Journal, Volume 22, Number 1, 2018.

Campbell, D. H. ( 2016). Starbucks: Social responsibility and tax avoidanceJ. of Acc. Ed.

Cham, H. T. (2016). Board diversity and corporate social disclosure: evidence from Vietnam.

Dharma, N. B. S. (2017). Pengaruh Corporate Social Responsibility Dan Capital Intensity Terhadap Tax Avoidance. E-Jurnal Akuntansi Universitas Udayana, Vol.18.1. Januari (2017): 529-556(ISSN: 2302-8556).

Doddy Setiawan, R. T. H. d. A. W. (2018). Dampak Karakteristik Dewan Direksi TerhadapPengungkapan Corporate Social Responsibility Pada Perusahaan Pertambangan Di Indonesia. MIX: Jurnal Ilmiah Manajemen, Volume VIII, No. 1, Feb 2018.

Hanlon, M. (2010). A Review of Tax Research Journal of Accounting and Economics Conference.

Hartono, J. (2006). Metodologi Penelitian Bisnis

Hoi, C.-K. (2013). Is Corporate Social Responsibility (CSR) Associated with Tax Avoidance? Evidence from Irresponsible CSR Activities.

https://mukhsonrofi.wordpress.com/2008/09/20/peraturan-atau-undangundang-terkait-fraud-dan-korupsi-sox-sarbanes-oxley-act/.Sarbanes

Oxley Act (2002), yang menetapkan untuk menghalangi akuntansi fraud.

Huang, S. K. (2013). The Impact of CEO Characteristics on CorporateSustainable Development. Corporate Social Responsibility and Environmental Management. 
Huseynov. (2012). Tax avoidance, tax management and corporate social responsibility. Journal of Corporate Finance, 18 (2012) 804-827.

Huseynov, F. (2017). Does index addition affect corporate tax avoidance? . Journal of Corporate Finance.

Ibrahim. (2003). Board Members in the services Industry : An empirical examination of the relationship between corporate social responsibility and directorial type. journal of business ethics, 47(4), 393-401.

Ibrahim, \& Angelidis. (1995). The Corporate social Responsives orientation of board members: are there diffrences between inside and outside directors? journal business ethics, 14(5), 405-410.

Jeongho Kim, C. I. (2017). Study on Corporate social responsibility (CSR) focus on Tax avoidance \& Financial Ratio analysis. sustainability journal.

Lako, P. D. A. (2011). Rekontruksi Menuju Akuntansi Berkelanjutan Paradigma Bisnis Dan Akuntansi. pidato pengukuhan guru besar ilmu akuntansi.

Lamade. (2020). Penanganan covid tak baik, investor asing lari. harian disway interview (18 september).

Lanis, R., \& Richardson, G. (2012). Corporate social responsibility and tax aggressiveness: a test of legitimacy theory Accounting, Auditing $\mathcal{E}$ Accountability Journal.

Lau, C. (2014). Corporate Social Responsibility in China: A CorporateGovernance Approach. Journal of Business Ethics, 136(1), 73-87.

Luft, J. (2003). Mapping management accounting: graphics and guidelines for theory consistent empirical research. Accounting Organization and Society.

M, M. H. (2018). Board Diversity and Accounting Conservatism: Evidence from Jordan International Business Research; Vol. 11, No. 7; 2018.

M.Al-Bassam, W. (2018). Corporate Boards and ownership structure as antecedents of corporate Governance disclosure in Saudi Arabian Publicly listed corporations. Business and society57.

Mangoting, J. H. d. Y. (2014). Pengaruh Struktur Kepemilikan Dan Karakteristik Dewan Terhadap Agresivitas Pajak. Tax \& Accounting Review, Vol 4, No 2.

Pandey, P. (2015). Research methodology tools and technique.

Peterson, D. d. (1995.). The Stakeholder Theory Of TheCorporation: Concepts, Evidence,And Implications. Academy of Managemeni Review, VoLM, No. 1, B5-91.

Pradipta, D. H. (2013). Pengaruh Corporate Social Responsibility (CSR), Profitabilitas, Leverage, dan Komisaris Independen Terhadap Praktik Penghindaran Pajak. Gajah Mada Journal of Accounting.

proffesional, L. (2012). Research Methodology.

Rahardjo, S. (2018). Pengaruh Corporate Social Responsibility Terhadap Financial Performance Dengan Tax Avoidance Dan Earning Management Sebagai Variabel Mediasi. $i$.

RI, U. U. (2007). Undang-undang Republik Indonesia nomor 40 tahun 2007 tentang perseroan terbatas. Sekretariat Negara. Jakarta.

Rodriguez-Dominguez, L. (2009). CG and Codes of Ethics. Jouurnal of Business Ethics, Vol 90- no 2. 
Salihu, I. A. (2013). Measures Of Corporate Tax Avoidance:Empirical Evidence From An Emerging Economy. International Journal of Business and Society, Vol. 14 No. 3, 2013, 412 - 427.

Sarwono, J. ( 2007). .analisis jalur untuk riset bisnis dengan spss. .analisis jalur untuk riset bisnis dengan spss.

Sepulveda, I.-M. G.-S. B. C.-B. C. (2014). Does media pressure moderate CSR disclosures by external directors?. Management Decision, Vol. 52 No. 6, 2014.

Suyanto, \& Supramono. (2012). Likuiditas, Leverage, Komisaris Independen, dan Manajemen Laba terhadap Agresivitas Pajak Perusahaan. Jurnal Keuangan dan Perbankan, 16(2).

Timothy. (2013). CSR and CG, Comparatives perspective. CG and international review, 21(5), 413-419.

Watson, L. (2015). Corporate Social Responsibility, TaxAvoidance, and Earnings Performance. American Accounting Association, JATA American Accounting AssociationVol. 37, No. 2.

williams, r. j. (2003). Women on corporate boards of directors and their influence on corporate philantropy. Journal Of Business Ethics, 42(1), 1-10.

Yogesh. (2006). Fundamental of research methodology and statistics.

Zhang, Y. (2016). Corporate Board And Corporate Social Responsibility Assurance: Evidence From China. Journal of Business Ethics.

Zhuang, Y. (2018). Board Composition and Corporate Social Responsibility Performance: Evidence from Chinese Public Firms. www.mdpi.com/journal/sustainability, Sustainability 2018, 10, 2752; doi:10.3390/su10082752. 